\title{
Perceived Benefits of Trademark Infringement Law to Thai Sports Industry
}

\author{
${ }^{1}$ Oam To-aj", ${ }^{1}$ Prasertchai Suksa-ard \\ ${ }^{1}$ Faculty of Social Sciences and Humanities, Mahidol University, Salaya, Nakhonpathum, Thailand.
}

Submitted 01 May 2020; Accepted in final form 31 June 2020.

\begin{abstract}
Background. The sports industry is comprised of a multitude of for-profit and non-profit organizations. It is therefore unsurprising that there are disputes between organizations and that some of these disputes center on the use of trademarks. Objectives. This study seeks to identify the perceived benefits of trademark infringement law in the Thai sports industry. Methods. This study employed a mixed-method design. In the quantitative phase was characterized by an initial quantitative phase of data collection by the questionnaire with 300 participants by selecting through nonprobability sampling, and analyzed with the descriptive statistic and factor analysis research method. In the qualitative phase, two people with legal expertise, two entrepreneurs, and two consumers participated in semi-structured interviews. Results. The results of the quantitative phase identified seven key components: 1) Ethics; 2) Needs; 3) Attitudes and values; 4) Product; 5) Society; 6) Law and 7) Economics with a total cumulative variance of 71.957 percent. The qualitative data confirmed the quantitative findings. Conclusion. An improved understanding and application of trademark infringement law would benefit the Thai sports industry.
\end{abstract}

KEYWORDS: Trademarks, Sports Industry, Sports Law, Sports Economy, Sports Products, Sports Society, Sports Ethic, Infringement

\section{INTRODUCTION}

The sport industry is comprised of a multitude of organizations. It is therefore unsurprising that there are conflicts between organizations (1) and that some of these disputes center on the use of trademarks. Efficiency in law means upholding the process of law enforcement with fairness under the rule of law (2). This concept of efficiency is pertinent to trademark law inside out outside of sport (3). Trademark infringement in sport is an economic crime due to changes from globalization and the information technology era, and these changes cause violations to occur very quickly which has led to the continuous development of so-called intellectual property (4). Creating intellectual property requires a lot of effort, skill, and resources (5). Inventing and creating are critical for a prosperous industry (6). Furthermore, trademarks are powerful and indispensable marketing tools. In the world of sports, their strategic use opens up significant commercial opportunities to generate income (7). Nowadays we rarely see a sport event without sponsorship. In most local or international sports events, sponsors have an important role and position (8), and this is also the benefit for the company in the issue of marketing strategy for attracting the attendants from many countries (9). The exchange of benefits may also lead to an exchange of brand image. Therefore, a brand sponsoring a property expects the goodwill associated with the property to transfer to the sponsor (8). On the other hand, trademark can cause massive damage to sports businesses, if there's an infringement. There is a concern within Thailand that attitudes towards trademarks are limit the professionalization of Thailand's sports industry. The capacity of Thai sport

*. Corresponding Author:

Oam To-aj, Ph.D

E-mail: Oam.deto@gmail.com 
organizations is increasing, in part because of the Thai government policies. This research examines sports trademark infringement law in the Thai sports industry. The purpose of the study is to identify the perceived benefit of trademark infringement law to Thai sports industry.

\section{MATERIALS AND METHODS}

This study utilized a mixed method design, beginning with a quantitative phase. This was followed by a qualitative phase using semi-structured interviews.

Quantitative Study

Participants. Three hundred people completed the quantitative survey. The sample was comprised of 100 people with legal expertise (i.e., judges, police officers, and intellectual property officers), 100 entrepreneurs and 100 consumers. All were selected through non-probability sampling.

Instrument. The researcher developed a questionnaire based on the previous literature. The survey consisted of external factors (economic, social, law, product, and attitude and value) and internal factors (ethics and needs) related to the perceived benefits of the trademark infringement law. The final survey comprised 33 items. The content validity of this survey was determined through Item-Objective Congruence (IOC) (10). Furthermore, the reliability was .85 (Cronbach's Alpha Coefficient). Questionnaires including 5 points of strongly agree, agree, neither agree nor disagree, disagree, strongly disagree.

Analysis. The quantitative data was analyzed through descriptive statistics including frequency, mean and standard deviation. The suitability of the data for factor analysis was measured using the KaiserMeyer-Olkin (KMO) statistic. A significance level of .05 was used for the Bartlett's Test of Sphericity (11).

\section{Qualitative Study}

Participants. The six participants included two people with legal expertise, two entrepreneurs and two consumers. Participants were again recruited using purposive sampling.

Procedures. The researchers discussed the findings from the quantitative process with the six participants. A semi-structured interview protocol guided the interview.

\section{RESULTS}

The factor analysis studied the correlation between the variable and the component for priority the factors. This was a two-step process.

Step 1. Verifying the fundamental data before analyzing the components in order to see the correlation of the information for analyzing by considering the fit of the data which was the statistic of Kaiser-Meyer-Olkin (KMO) and the statistic of Bartlett's Test. Table 1 shows the testing result of KMO and Bartlett's Test of analyzing the perceived benefits of trademark infringement law.

Table 1. The testing result of KMO and Bartlett's Test Kaiser-Meyer-Olkin Measure of Sampling 0.915 Adequacy

Bartlett's test of sphericity

Approx. chi-square

Df

Sig

Table 1 shows that Kaiser-Meyer-Olkin (KMO) equaled 0.915 which means the data and the variable were related, and could be used the data for the hypothesis testing (Bartlett's Test of Sphericity).The Chi-square value equals 7270.439 , and the statically significant at 0.00 which was less than 0.5 . It also showed that the correlation matrix of the variables was related.

The factor analysis on the use of the trademark infringement law among sports-industry stakeholders is shown in Table 2.

Table 2. Seven Components Identified Through Factor Analysis

\begin{tabular}{lccc}
\hline Component & Eigenvalues & Contributing Variance (\%) & Cumulative Variance (\%) \\
\hline Ethics & 3.904 & 11.831 & 11.831 \\
Needs & 3.744 & 11.346 & 23.178 \\
Attitude and value & 3.669 & 11.117 & 34.295 \\
Products & 3.599 & 10.905 & 45.200 \\
Society & 3.071 & 9.306 & 54.506 \\
Law & 3.023 & 9.160 & 63.665 \\
Economy & 2.736 & 8.292 & 71.957 \\
\hline
\end{tabular}

Table 2 shows the extraction of seven primary components by Principal Component Analysis with Eigenvalues ranging from 2.736 - 3.904 with the total cumulative variance of 71.957 percent. From the factor loading results after rotating by orthogonal rotation using the Varimax Method, the analysis showed seven priority components as follows:

Factor 1 was the ethics factor (Eigenvalue: 3.904). Factor 2 was the needs factor (Eigenvalue: 3.744).
Factor 3 was the attitude and value factor (Eigenvalue: 3.669). Factor 4 was the product factor (Eigenvalue: 3.569). Factor 5 was the social factor (Eigenvalue: 3.071). Factor 6 was the law factor (Eigenvalue: 3.023). Factor 7 was the economic factor (Eigenvalue: 2.736).

Step 2. The component rotation was used by orthogonal rotation using the Varimax Method. Refer Table 3 below. 
Table 3. The Component Loading of the Factor Analysis

\begin{tabular}{|c|c|c|c|c|c|c|c|}
\hline \multirow{2}{*}{ Items } & \multicolumn{7}{|c|}{ The component loading } \\
\hline & 1 & 2 & 3 & 4 & 5 & 6 & 7 \\
\hline \multicolumn{8}{|l|}{ 1. The economic factors } \\
\hline Distributing the product in many levels & & & & & & & 0.777 \\
\hline Observing the changing and the trend of the economic growth & & & & & & & 0.801 \\
\hline Proceeding the business with caution & & & & & & & 0.738 \\
\hline Consulting with the economic specialist & & & & & & & 0.561 \\
\hline Studying in the business strategy & & & & & & & 0.334 \\
\hline \multicolumn{8}{|l|}{ 2. The social factors } \\
\hline Making the member to live peacefully & & & & & 0.785 & & \\
\hline $\begin{array}{l}\text { Creating the fairness by allocating the benefits to the member base on their } \\
\text { works }\end{array}$ & & & & & 0.725 & & \\
\hline Driving to have the creative thinking & & & & & 0.676 & & \\
\hline Creating the new innovation for the society growth & & & & & 0.398 & & \\
\hline $\begin{array}{l}\text { Creating the awareness to the people in the society, and teaching the kids } \\
\text { to behave well }\end{array}$ & & & & & 0.700 & & \\
\hline The community needs to stop the opportunity of committing the crime & & & & & 0.421 & & \\
\hline \multicolumn{8}{|l|}{ 3. The law factors } \\
\hline $\begin{array}{l}\text { The interpreting and legislating need to be considered in the law's } \\
\text { objective and the constitution right }\end{array}$ & & & & & & 0.547 & \\
\hline $\begin{array}{l}\text { When occurs the law's gap, the comparative law, the customary law, the } \\
\text { principal of the law should be used }\end{array}$ & & & & & & 0.502 & \\
\hline The law should have the decisive punishment & & & & & & 0.808 & \\
\hline Should have the decisive law enforcement for the fairness and equality & & & & & & 0.803 & \\
\hline \multicolumn{8}{|l|}{ 4. The product factors } \\
\hline Defining the product's standard into the same criteria & & & & 0.690 & & & \\
\hline $\begin{array}{l}\text { Defining the details of the trademark infringement product which affects } \\
\text { the consumer's buying decision }\end{array}$ & & & & 0.587 & & & \\
\hline The difficulty to approach the product & & & & 0.722 & & & \\
\hline \multicolumn{8}{|l|}{ 5. The attitude and the value factors } \\
\hline Understanding in the product buying selection & & & 0.425 & & & & \\
\hline Never support the infringement consumer & & & 0.558 & & & & \\
\hline Don't have the value in using the world-class product & & & 0.775 & & & & \\
\hline Having a very good attitude for the society & & & 0.695 & & & & \\
\hline Respecting the law & & & 0.661 & & & & \\
\hline Thinking about the society's benefit more than oneself & & & 0.636 & & & & \\
\hline \multicolumn{8}{|l|}{ 6. The needs factors } \\
\hline Without using the brand-named product, you can be loved by others & & 0.771 & & & & & \\
\hline $\begin{array}{l}\text { Without being the owner of the infringement brand-named product, you } \\
\text { can be loved by others }\end{array}$ & & 0.791 & & & & & \\
\hline Without using the brand-named product, you can be safe and healthy & & 0.810 & & & & & \\
\hline Without using the brand-named product, you can be the famous athlete & & 0.768 & & & & & \\
\hline \multicolumn{8}{|l|}{ 7. The morale and the ethics factors } \\
\hline Building the toleration for not to use the trademark infringement product & 0.679 & & & & & & \\
\hline Keep the good moral and ethics as a traditional Thai & 0.774 & & & & & & \\
\hline $\begin{array}{l}\text { Living by using the philosophy of the sufficient economy from King } \\
\text { Rama } 9\end{array}$ & 0.734 & & & & & & \\
\hline Strength in physical and mental & 0.736 & & & & & & \\
\hline Keep the good moral and ethics to others & 0.733 & & & & & & \\
\hline
\end{tabular}

Table 3 identifies seven factors. First, the moral and ethics factor consisted of five variables with the component ranging from $0.679-0.774$. Second, the four needs variables ranged from $0.768-0.810$. Third, the six attitude variables ranged from $0.425-0.775$. Fourth, the three product variables ranged from 0.587 -0.722 . Fifth, five society variables ranged from 0.398 - 0.785. Sixth, the four law variables ranged from $0.502-0.808$. Last, the economic five variables ranged from $0.334-0.801$.

The qualitative findings verified the seven factors from the quantitative phase. One participant remarked, "The priority ordering of those factors are proper, I do agree with that". Furthermore, the researchers can be concluded into each factor for finding the relation between the quantitative and qualitative parts in this research as follows: The moral and ethics factor which related to the key informant A who said, "The moral and the ethics factor is very important priority to promote, the related person should set the plan in many stages in the issue of giving the knowledge in the punishment of committing the crimes to people". The needs factor which related to the key informant B who indicated that "Even the expensive product might have the same quality as the trademark infringement product". The attitude and value factor which related to one of the key informant $\mathrm{C}$ who expressed that "People should think about the society's benefit more than oneself". The product factor which related to one of the key informant D who revealed that "Easy to find the worldclass products with the very good prices because there are so many sport exhibitions these days and the trademark product creates the fundamental relationship between product and consumer" The social factor which related to the key informant $\mathrm{E}$ who explained that "Creating the new innovation for the 
society growth is the important thing that all the entrepreneurs should do". The law factor which related to the key informant $\mathrm{F}$ who discussed that "Some people may not understand the law, but the law supports every department in the organization". The economic factor which related to the key informant $G$ who presented that "The operational obstacle is the limitation which comes from the external environment. Lacking awareness in the difficult time might be affect towards the consumer's buying decision".

\section{DISCUSSION}

The findings of this study are consistent with previous research about the factors affecting product infringements of Chiang Mai's teenage consumers. This research showed how different cultural, social, and psychological factors changed product consumption patterns (12).

Component 1 was the ethical consideration, similar to that of the sufficiency economy philosophy (13), the stages of moral development (14), the moral intelligence theory (15), the locus of control theory (16). This finding is supported by a previous study which concluded with a discussion of how to use of these trademark does not fulfill the three principles of social responsibility which are human dignity, truthtelling, and nonmaleficence (17).

Component 2 is concerned with needs, as seen in economic development theory (18), and Maslow's Hierarchy of Needs (19). These needs defined essentials of living, such as the needs to be accepted by friends, the needs to be famous, and the needs to be healthy and secure. There is support from previous research which shows that the satisfaction of each higher-level need was statistically predicted by the satisfaction of the need immediately below it (20).

Component 3 concerned attitudes and values, as part of social learning theory (21) which deals with the level of acceptance of ideas. According to Gregory and James (22) values are an important predictor of attitudes and behavioral intentions.

Component 4 concerned the product, as seen in marketing theory and practice (23) which involved setting product standards and distinguishing one's product. Trademark infringement can enhance consumer confusion and subsequently impact consumer decision making. Furthermore, it is also relevant to another study which found that moderately famous sport trademarks suffered dilutive harm from customers, whereas exceptionally famous marks were immune to dilution effects (24).

Component 5 is concerned the social implications of the law as seen in the social exchange theory (25), and the structural-functional approach (26). It is supported by previous research which identified several key mechanisms to help increase customers' trust of ecommerce and decrease privacy concerns (27).

The previous article provided an introduction to the jurisprudence of trademark law particularly related to sport properties or organizations and the use of survey evidence in trademark litigation (28). This relates to Component 6 and the nature of the legal framework as seen in hermeneutics theory and the interpretation of legal theory (29).

The previous study of Chapagai (30) supported Component 7 and the effect on the economy (18). Economic perspectives of trademark were also relevant to many types of Nepalese businesses, including manufacturing, services and entrepreneurship (18).

\section{CONCLUSION}

From the research's findings, it can be concluded that the moral issue was one of the very important factors. This not surprising because if every person was guided by morals, then infringements are not likely to occur. Another important point is the fundamental relationship between the law and marketing (31). From the marketer's perspective trademarks and brands cannot be separated. A brand is as the representative of a company image, which builds and develops over time by creating trust, while a trademark provides legal protection for the brand (32).

A major method in reducing the trademark infringement in Thailand is to respect the law, and apart from anything else, Thai people should follow King Bhumibol Adulyadej Rama 9's philosophy which has been proved that it is a good thing and useable, and also each country shall to adapt this theory into their own context (13). Moreover, the government should arrange practical seminar training providing knowledge to stakeholders in Thailand, and facilitate meetings with specialists and academics which informs stakeholders of policies and practical guidelines useful for Asia-Pacific Economic country members. In the end, the government should campaign against the sale and purchase of trademark-infringing products.

One limitation of this research was the data gathered came from a limited sample group. To provide future generalizability research should collect the data from a larger, more diverse population. Future research on trademark infringement should consider Thai attitudes towards ambush marketing (33). Another opportunity is understanding the perceived benefits of trademark law in other countries, especially those with more relaxed or more stringent approaches to trademark law.

\section{APPLICABLE REMARKS}

- This research is innovative law research because of its empirical foundations.

- The seven priority components enable people and organizations to more easily prioritize tasks to solve infringement law problems.

- An improved understanding and application of trademark infringement law would clearly benefit the Thai sports industry. 


\section{REFERENCES}

1. Zheng J, Lau P, Chen S, Dickson G. Interorganisational conflict between national and provincial sport organisations within China's elite sport system: Perspectives from national organisations. Sport Manage. 2018;22(5):667-681. doi: 10.1016/j.smr.2018.10.002

2. Gammelsaeter H. Sport is not industry: bringing sport back to sport management. Eur Sport Manag $Q$. 2020(2):224. doi: 10.1080/16184742.2020.1741013

3. Parchomovsky G, Bell A. Restructuring copyright infringement. Tex Rev Law Polit. 2020;98(4):679733.

4. Cahoy DR, Oswald LJ. A serendipitous experiment in percolation of intellectual property doctrine. Ind LJ. 2020;95(1):39-86.

5. Albov AP, Kupriyanova LM, Gorbunov ZN, Nasonkin VV, Kamyshansky VP. Harmonizing the customs laws of the European union and the Russian federation used for protecting intellectual property rights. Rev Incl. 2020;7(3-6):163-177.

6. Thurheimer T. Crimson chaos: Sports team trademarks in artwork and the functionality doctrine. $J$ Int Commer Law Technol. 2012;7(1):27-43.

7. World intellectual property organization. The International Trademark System and Sports. [place unknown]: World intellectual property organization 2019 [2020 May 10]. Available from: https://www.wipo.int/ipoutreach/en/ipday/2019/madrid_trademarks_sports.html.

8. Keshkar S, Dodds MA, Lawrence I, Morris E. The Role of Culture in Sports Sponsorship: an Update. Ann Appl Sport Sci. 2019;7(1):57-81. doi: 10.29252/aassjournal.7.1.57

9. Yongjae K, Jeeyoon K, Sungho C, Yim K. The impact of mega sporting events on host country's destination images: The cases of the 2014 Sochi winter olympics and 2015 Beijing IAAF world championships. Sport Mark Q. 2019;28(3):148-164. doi: 10.32731/SMQ.283.092019.03

10.Perez-Rojo G, Noriega C, Velasco C, Lopez J. Development and assessment of the content validity of the professional good practices scale in nursing homes. Int Psychogeriatr. 2019;31(10):1517-1521. doi: 10.1017/S1041610218002077 pmid: 30522536

11.Hadia UN, Abdullaha N, Sentosaa I. An easy approach to exploratory factor analysis: Marketing perspective. JESR. 2016;6(1):215-223. doi: 10.5901/jesr.2016.v6n1p215

12. Baudouin BS, Wongsawat P, Sudnongbua S. Factors affecting the preventive intention on premarital sexual behaviours among junior high school students in lower-northern region of Thailand. Int J Adolesc Youth. 2020;25(12):712-724. doi: 10.1080/02673843.2020.1728560

13. Thummathai K, Sethabouppha H, Chanprasit C, Lasuka D. Depression prevention in adolescents based on Buddhism and Sufficiency Economy Philosophy. Arch Psychiatr Nurs. 2020;34(1):70-74. doi: 10.1016/j.apnu.2019.10.005 pmid: 32035593

14. Susilawati S, Rahmaniah A, Yasin AF, Wahidmurni Maseleno A. Moral learning in forming moderate muslims on islamic college in MALANG. Int J Psychosoc Rehabil. 2020;24(3):2040-2048. doi: 10.37200/IJPR/V24I6/PR260194

15.Rieder TN, Hutler B, Mathews DJH. Artificial intelligence in service of human needs: Pragmatic first steps toward an ethics for semi-autonomous agents. AJOB Neurosci. 2020;11(2):120-127. doi: 10.1080/21507740.2020.1740354 pmid: 32228385

16.Dodourova M, Clarkin JE, Lenkei B. The die is cast: Brexit's influence on student career intentions. Stud High Educ. 2020;45(3):648-664. doi: 10.1080/03075079.2019.1593346

17. Mcnealy JE. Disparaging trademarks and social responsibility. Sport Ethics Philos. 2018;12(3):304-316. doi: 10.1080/17511321.2017.1360383

18. Bazan C, Gaultois H, Shaikh A, Gillespie K, Frederick S, Amjad A. A systematic literature review of the influence of the university's environment and support system on the precursors of social entrepreneurial intention of students. J Innov Entrep. 2020;9(12):4. doi: 10.1186/s13731-020-0116-9

19. Chruzik K. Risk management in crisis. J KONBiNO. 2020;49(12):245-264. doi: 10.2478/jok-2019-0085

20. Taormina RJ, Gao JH. Maslow and the motivation hierarchy: measuring satisfaction of the needs. Am J Psychol. 2013;126(2):155-177. doi: 10.5406/amerjpsyc.126.2.0155 pmid: 23858951

21.Rosenstock IM, Strecher VJ, Becker MH. Social learning theory and the health belief model. Health Educ Q. 1988;15(2):175-183. doi: 10.1177/109019818801500203 pmid: 3378902 
22. Gregory MR, James OM. Relations between values, attitudes, and behavioral intentions: The moderating role of attitude function. J Exp Soc Psychol. 1995;31(3):266-285. doi: 10.1006/jesp.1995.1013

23. Kotler P. Contributions to marketing theory and practice. Rev Market Res. 2011;8:87-120. doi: 10.1108/S1548-6435(2011)0000008007

24. Cho S, Won J, Lucy JL, Kwan JL. Empirical investigation of sport trademark dilution using contingent valuation method. Sport Mark Q. 2019;34(3):189-200. doi: 10.1123/jsm.2019-0174

25.Edward JL, Shane RT. Bringing emotions into social exchange theory. Annu Rev Sociol. 1999;25(8):217244. doi: 10.1146/annurev.soc.25.1.217

26. Dardo RL, Cavallero L, Brizuela MA, Aguiar MR. Ecosystemic structural-functional approach of the state and transition model. Appl Veg Sci. 2011;14(1):6-16. doi: 10.1111/j.1654-109X.2010.01095

27.Luo X. Trust production and privacy concerns on the Internet: A framework based on relationship marketing and social exchange theory. Bus Hist. 2002;32(2):111-118. doi: 10.1016/S00198501(01)00182-1

28. Cho S, Moorman A. An examination of the psychometrical comparability of survey evidence in sport trademark litigation. J Legal Aspects of Sport. 2014;24(1). doi: 10.1123/jlas.2013-0010

29. Macgno F, Walton D, Sartor G. Pragmatic maxims and presumption legal interpretation. Law Philos. 2018;37(2):69-115. doi: 10.1007/s10982-017-9306-4

30.Chapagai R. Economic perspectives of trademarks. Nep JOL. 2018;9:73-83. doi: 10.3126/sj.v9i0.20882

31. World intellectual property organization. The role of trademarks in marketing [Internet]. [place unknown]: World intellectual property organization 2002 [2020 June 15]. Available from: https://www.wipo.int/export/sites/www/sme/en/documents/wipo_magazine/02_2002.pdf.

32.Brunner R. Luxembourg: Brand and trademark: Where marketing meets law. [place unknown]: Dennemeyer group 2018 [2020 June 15]. Available from: https://www.mondaq.com/IntellectualProperty/733436/Brand-And-Trademark-Where-Marketing-Meets-Law.

33. Dickson G, Naylor M, Phelps S. Consumer attitudes towards ambush marketing. Sport Manage Rev. 2015;18(2):280-290. doi: 10.1016/j.smr.2014.07.001 